\title{
Pengalaman Personal Hygiene Pada Santri Putra Dengan Penyakit Scabies Di Pondok Pesantren Darullughah Wal Karomah Sidomukti Kraksaan Probolinggo
}

\section{Husnul Khotimah 1, Sri Astutik Andayani 2, Robiyatul Maulidah3}

1. Universitas Nurul Jadid, Probolinggo

2. Universitas Nurul Jadid, Probolinggo

3. Universitas Nurul Jadid, Probolinggo

\section{Abstract}

Scabies is a skin disease caused by an infestation of the sarcoptes scabie mite, which is transmitted by direct human contact and indirect human contact. The problem of santries experiencing scabies is related to their poor personal hygiene, because each individual has different characteristics in maintaining personal hygiene. This research is qualitative research, the research subjects are male santries of junior high school and high school darullughah wal karomah sidomukti kraksaan probolinggo. data collection methods used observation, interviews, and documentation. This qualitative research with a phenomenological approach aims to obtain in-depth information about personal hygiene exsperinces of male santries in islamic boarding schools. Five participants were selected based on the research criteria and were saturated. Focusing selective analysis (the selective or high-painting approach) was used in data analysis. four themes identified in this research: 1) personal hygiene experience for santries 2) the environment around the santris 3) the impact of scabies on the 
santries 4) the handling of the satries in dealing wiht scabies. The results of this research indicate: 1) there is a description of how santries maintain ther personal hygiene properly in islamic boarding school, namely that clothes and toiletries are not used interchangedably 2) there is description of how the santris protect the environmennt around the santries 3)there is an illustration of the impactt that will arise when santris experience scabies. 4) there is a description of how the santris can overcome scabies in islamic bording schools

Keywords: experience, personal hygiene, scabies

\section{Abstrak}

Scabies suatu penyakit kulit yang disebabkan oleh infestasi tungau Sarcoptes scabie, yang penularannya secara kontak langsung manusia dan juga secara tidak kontak langsung manusia. Permasalahan santri yang mengalami scabies yaitu terkait personal hygienenya yang kurang baik, karana setiap individu mempunyai karakter yang berbeda-beda dalam mejaga personal hygienenya. Penelitian ini merupakan penelitian kualitatif, subyek penelitian adalah santri putra SMP dan MA Darullughah Wal Karomah Sidomukti Kraksaan Probolinggo. Metode pengumpulan data yang digunakan observasi, interview (wawancara), dan dokumentasi. Penelitian kualitatif dengan pendekatan fenomenologi ini bertujuan untuk memperoleh informasi yang 
mendalam tentang pengalaman personal hygiene pada santri putra dengan penyakit scabies di pondok pesantren. Lima partisipan dipilih berdasarkan kriteria penelitian dan telah tersaturasi. Analisis selektif fokusing (the selective or highlingting approach) di pergunakan dalam analisis data. Empat tema terindentifikasi dalam penelitian ini : (1) pengalaman personal hygiene pada santri (2) keadaan lingkungan sekitar santri (3) dampak scabies pada santri (4) penanganan santri dalam mengatasi scabies. Hasil penelitian ini menunjukkan : (1) Adanya gambaran tentang bagaimana santri menjaga personal hygiene dengan baik di pondok pesantren yaitu pakaian atau alat mandi tidak digunakan secara bergantian, karena kebersihan personal hygiene sangat berpengaruh pada penyakit kulit seperti scabies (2) adanya gambaran bagaimana santri menjaga lingkungan disekitar santri (3) adanya gambaran dampak apa yang akan timbul saat santri mengalami penyakit scabies (4) adanya gambaran bagaimana santri dapat mengatasi penyakit scabies di pondok pesantren.

Kata Kunci: Pengalaman, personal hygiene, scabies 
Pendahuluan

Scabies

merupakan

penyakit

kulit

yang

dapat

ditularkan lewat kontak langsung manusia (Luthfa, dkk, 2019) Scabies juga merupakan penyakit kulit dengan insidensi yang tinggi di seluruh dunia, terutama di daerah beriklim tropis dan subtropis. Selain itu morbiditas dan mortalitas penyakit kulit ini pada dasarnya disebabkan oleh infeksi bakteri sekunder (Bernigaud, charlotte samarawickrama, 2019). Berdasarkan study pendahuluan pada bulan desember tahun 2019 di pondok pesantren Darullughah Wal Karomah Sidomukti Kraksaan Probolinggo, dari study pendahuluan hasil data santri dengan scabies yang diperoleh peneliti pada bulan november-desember, siswa MA terdapat 91 siswa dengan scabies 13 siswa, siswa SMK terdapat 105 siswa dengan scabies 6 siswa, siswa MTs terdapat 144 siswa dengan scabies 40 siswa, siswa SMP terdapat 101 dengan scabies 24 siswa, jumlah santri keseluruhan terdapat 441 santri dengan scabies terdapat 83 santri.

Scabies

merupakan penyakit infeksi menular yang disebabkan oleh tungau Sarcoptes scabei var hominis (Hilma, Dkk, 2014). Penyebab skabies juga terjadi karena personal hygiene yang kurang baik terutama di kalangan santri (Mayrona, Sindy Tia Subchan, 2018) Seperti kondisi lingkungan pesantren dan kepadatan hunian dapat mempengaruhi

kesehatan santri, diantaranya dalam penularan scabies (Sumiatin, Dkk, 2017) Memelihara personal hygiene berarti tindakan menjaga kebersihan dan kesehatan diri seseorang untuk kesejahteraan 


\section{Husnul Khotimah: Pengalaman Personal Hygiene}

fisik dan psikisnya (Susanto, Dkk, 2017). Personal hygiene atau kebersihan diri perorangan juga perlu diaplikasikan pada diri pribadi untuk meningkatkan derajat kesehatan (Herdyana, Erma Qomari, 2016) Adapun faktor yang berperan dalam tingginya prevalensi scabies terkait dengan personal hygiene yang kurang, masih banyak orang yang tidak memperhatikan

personal hygiene karena hal-hal seperti ini dianggap tergantung kebiasaan seseorang, jadi personal hygiene yang buruk dapat menyebabkan tubuh terserang berbagai penyakit seperti penyakit kulit (Desmawati Dewi, Dkk, 2015).

Adapun contoh kejadian scabies yang berhubungan dengan personal hygiene berdasarkan penelitian (Ma'rufi, 2005) ialah pada santri Pondok
Pesantren Lamongan, penilaian hygiene perorangan dalam penelitian tersebut meliputi frekuensi mandi, memakai sabun atau tidak, penggunaan pakaian dan handuk bergantian, dan kebersihan alas tidur. Perilaku yang mendukung santri mudah terserang scabies karena sering memakai baju atau handuk bergantian dengan teman serta tidur bersama dan berhimpitan dalam satu tempat tidur (Mufidah, Dkk, 2016)

Metode

Jenis penelitian penelitian ini dengan pendekatan kualitatif digunakan untuk memperoleh informasi yang menyeluruh dan mendalam tentang pengalaman personal hygiene pada santri putra dengan penyakit scabies di Pondok Pesantren Darullughah wal karomah Sidomukti Kraksaan Probolinggo. 


\section{Husnul Khotimah: Pengalaman Personal Hygiene}

Pendekatan ini juga memberikan peluang bagi partisipan untuk berbagi cerita dan pengalaman personal hygienenya berdasarkan perspektif individual. Analisa Transkiptranskrip dari hasil wawancara dan catatan lapangan (field notes) yang telah dibuat peneliti secara bersamaan di analisis. Tehnik analisis spesifik dengan menggunakan pendekatan analisis selektif dan focusing (the selective or highlighting approach)

\section{Hasil Penelitian}

1. Distribusi Karakteristik Partisipan.

Tabel 1: Distribusi

Karakteristik partisipan

\begin{tabular}{cccccc}
\hline P & JK & U & Agama & Pendidikan & Pekerjaan \\
\hline P1 & LK & 16 & Islam & MA & Pelajar \\
\hline P2 & LK & 13 & Islam & SMP & Pelajar \\
\hline P3 & LK & 13 & Islam & SMP & Pelajar \\
\hline P4 & LK & 13 & Islam & SMP & Pelajar \\
\hline P5 & LK & 13 & Islam & SMP & Pelajar \\
\hline
\end{tabular}

Sumber: Angket Penelitian

Dari tabel 1 diatas didapatkan hasil bahwa Partisipan dalam penelitian ini berjumlah 5 orang, dengan jenis kelamin laki-laki semua, berusia antara 13-16 tahun. Partisipan pertama berumur 16 tahun, partisipan ke dua berumur 13 tahun, partisipan ke tiga berumur 13 tahun, partisipan ke empat berumur 13 tahun, partisipan ke lima berumur 13 tahun. Dari lima partisipan beragama islam, pendidikannya satu dari lima partisipan kelas 1 MA, empat dari lima partisipan kelas 1 SMP, status dari lima partisipan sebagai pelajar.

\section{Analisis Tema}

Berdasarkan

Transkrip dari hasil wawancara dan catatan lapangan yang di buat peneliti bersamaan di analisis. Sehingga mendapatkan 4 tema yaitu: pengalaman personal hygiene pada santri, keadaan lingkungan sekitar santri, dampak scabies pada santri, penanganan 


\section{Husnul Khotimah: Pengalaman Personal Hygiene}

santri dalam mengatasi scabies. Semua akan di uraikan satu persatu.

a. Pengalaman personal hygiene pada santri

Scabies suatu penyakit yang sering di alami oleh santri, banyak hal yang dapat menimbulkan scabies yang mana dari hasil wawancara kepada partisipan mendapat empat sub-tema yaitu : penularan scabies secara kontak langsung manusia, alat mandi santri, pakaian santri, dan gejala yang muncul pada santri. Berikut ini penjelasan dari beberapa sub-tema yang peneliti dapat:

1) Penularan scabies secara kontak langsung manusia Tiga dari lima partisipan mengatakan bahwa scabies penularannya secara kontak langsung manusia, berikut ungkapan dari mereka :

“...Penyakit gatal-gatal adalah penyakit, yang terjadi secara spontan dengan manusia..."(P1) "...Penyakit yang penularannya kontak manusia...(P4)

“...yang saya ketahui tentang penyakit gatalgatal adalah, penyakit, penyakit yang penularannya secara kontak manusia..."(P5)

Partisipan meng atakan bahwa penularan scabies terjadi secara kontak langsung manusia.

2) Alat mandi santri

Alat mandi merupakan penyebab terjadinya scabies, apalagi digunakan secara bergantian antara santri yang terkena scabies dan santri yang tidak terkena scabies, karna ini bisa menularkan kepada santri yang tidak terkena scabies. Dari kejadian tersebut empat 


\section{Husnul Khotimah: Pengalaman Personal Hygiene}

dari lima partisipan sadar

panggunaan mandinya.

ungkapan

:“...Saya memakai alat mandi saya, dengan, milik saya sendiri, memang dulu saya, memakai alat mandi saya, bersamaan dengan dengan temen-temen, saat saya terkena gatelgatel, saya sadar maka saya memakai alat mandi saya pernah ganti-ganti dan di pinjam..."(P2)

"...Pakek sabun sendiri bak..."(P4) “...Saya tidak memperbolehkan temen saya meminjam anduk saya lagi, dan tidak memperbolehkan temen saya meminjam alat mandi saya, dan saya tidak meminjam alat mandi temen saya..."(P5).

Partisipan mengatakan bahwa memakai alat mandinya sendiri.

3) Pakaian santri

Pakaian santri juga faktor penyebab sendiri...”(P1) “...Tidak terjadinya scabies, apalagi di gunakan secara bergantian. Tiga dari lima partisipan sadar sudah tidak bergantian dalam pakaian santri. Berikut ungkapan santri :

“...Saya tidak pernah meminjamkan kepada, anak-anak, saya, memakai baju saya sendiri, tidak pernah memperpinjamkan..."(P

1)

“...Penggunaan

pakaiannya, saya tidak pernah, di pinjamkan, kepada tementemen..."(P2)

“...Saya tidak pernah, tidak pernah meminjam, pakaian temen saya lagi, dan tidak pernah meminjam, handuk temen saya lagi, dan, dan saya tidak memperbolehkan temen saya meminjam pakaian saya dan handuk saya..."(P5) 


\section{Husnul Khotimah: Pengalaman Personal Hygiene}

Partisipan mengatakan bahwa memakai pakaiannya sendiri tidak meminjam ataupun

diperpinjamkan.

4) Gejala yang muncul pada santri

Scabies menimbulkan gejala gatal pada santri yang mengalaminya, gejala tersebut sering terjadi pada malam hari. Tiga dari lima partisipan mengatakan sering gatal pada malam hari. Berikut ungkapan partisipan :

“...Yang terjadi, sering terjadi, maksudnya sering terjadi pada malam hari..."(P1)

“...Biasanya gatal pada malam hari..."(P4)

“...Biasanya gatal pada malam hari..."(P5)

Partisipan mengatakan bahwa gejala scabies yang sering muncul yaitu rasa gatal pada malam hari. b. Keadaan

lingkungan sekitar santri

Lingkungan

sangat berpengaruh dalam kejadian scabies jika kondisi lingkungan santri kotor maka akan sangat beresiko terjadinya scabies. Sub tema yang dapat di ambil dari partisipan oleh peneliti yaitu perubahan

lingkungan. Berikut penjelasannya dari sub-tema tersebut :

1) Perubahan

lingkungan sekitar santri

Tiga dari lima partisipan

menyadari untuk menjaga

lingkungan sekitar santri. Berikut ungkapan partisipan : “...Menjaga kebersihan disekitar daerah saya, kalau ada sampah 


\section{Husnul Khotimah: Pengalaman Personal Hygiene}

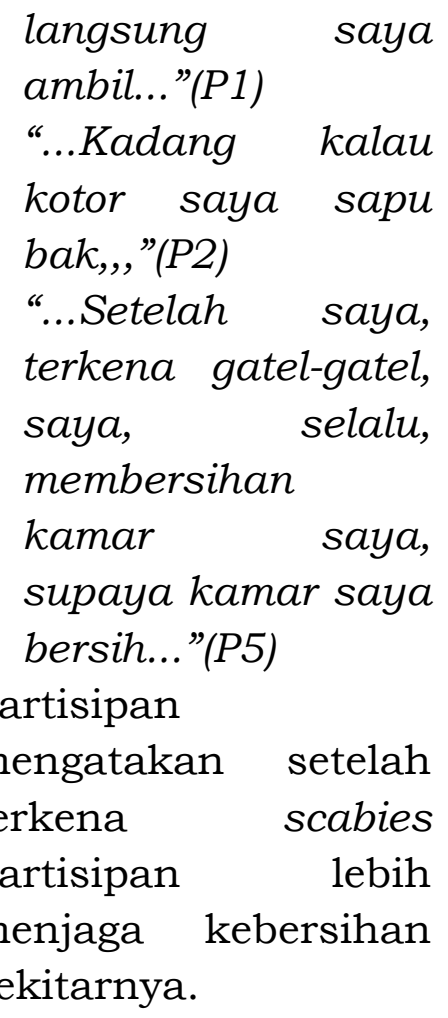

\section{c. Dampak scabies pada santri}

Scabies yang di alami santri menimbulkan dampak dalam kehidupan seharihari santri di pondok pesantren. Dampak tersebut akan menimbulkan berbagai perubahan pada kehidupan sehari-hari santri. Seperti dua sub- tema yang dapat di ambil dari partisipan, perubahan belajar santri, perubahan pola tidur. Berikut penjelasannya dari sub-tema tersebut :

1) Perubahan belajar santri

Empat dari lima partisipan

mengatakan saat terkena scabies belajar santri jadi terganggu, tidak maksimal, juga merasa jadi tidak enak. Berikut ungkapan dari ke empat partisipan : “...Aktifitas

sekolah saya, tidak maksimal, terganggu..."(P1) "...Biasanya, belajar enak, biasanya belajar enak tiba-tiba jadi tidak enak..."(P2) “...Belajar jadi tidak fokus..."(P4) “...Biasanya saya sering menulis di sekolah, dan sekarang saya jarang nulis di 


\section{Husnul Khotimah: Pengalaman Personal Hygiene}

$\begin{array}{ll}\text { sekolah } & \text { karna } \\ \text { mempunyai } & \\ \text { penyakit } & \text { gatal- } \\ \text { gatal..."(P5) } & \end{array}$

Partisipan

mengatakan bahwa aktifitas belajarnya terganggu karna terkena scabies.

2) Perubahan pola tidur santri

Selain sekolah terganggu penyakit scabies ini menyebabkan pola tidur santri juga menjadi terganggu, yang biasanya santri tidur dengan nyenyak saat terkena scabies tidur santri menjadi tidak nyenyak, sering juga terbangun di malam hari karena merasa gatal. Dari kelima partisipan berikut ini ungkapanya :

“...Tidur saya, kayak gak merasa enak itu bak, kayak gak nyenyak, merasa gatal, merasa terganggu..."(P1) "...Biasanya tidur nyenyak dan bangun pagi, dan, sekarang terbangun malam karena gatal..."(P2) "...Kesulitan mau tidur, karena gatel bak..."(P3)

“...Tidurnya tidak nyenyak bak..."(P4)

"...Biasanya saya tidur nyenyak dan sekarang tidak nyenyak, dan biasanya tidurnya pulas sekaraang tidak pulas..."(P5)

Partisipan

mengatakan bahwa tidurnya tidak nyenyak karna rasa gatal yang mengganggu.

d. Penanganan santri dalam mengatasi scabies

Beberapa upaya
santri dalam
menangani scabies
berbeda-beda,
seperti periksa,
diberi salep, mandi




\section{Husnul Khotimah: Pengalaman Personal Hygiene}

air laut dan kompres air hangat. Dari hal diatas peneliti mendapat satu subtema dari partisipan. Seperti berikut penjelasannya :

1) Penanganan santri dengan memberi salep

Dua dari lima partisipan

mengatakan cara santri dalam menangani scabies dengan cara di beri salep. Berikut ungkapan dari partisipan :

“...Pengobatannya, dikasik pil sama kesehatan bak, periksa keluar dan kasik salep..."(P3) “...Pakai salep, sama obat bak..."(P4)

Partisipan dalam menangani scabies yaitu dengan memakai salep.

2) Penanganan santri dengan periksa Tiga dari lima partisipan mengatakan periksa keluar saat rerkena scabies. Berikut ungkapan dari partisipan : “....Kalau obat saya periksa keluar bak, dan dapat obat, tapi saya lupa namanya bak...(P1) “...Pengobatannya, dikasik pil sama kesehatan bak, periksa keluar dan beli salep..."(P3) “...Di,,suntik, di bawa pulang dan di suntik dan kembali lagi ke pondok kalau sudah sembuh..."(P5)

Partisipan menangani scabies yaitu dengan cara pergi periksa.

3) Penanganan santri dengan mandi air laut

Satu dari lima mengatakan mengatasi scabies dengan mandi air laut dan kompres air hangat. Berikut ungkapan dari partispan : 


\section{Husnul Khotimah: Pengalaman Personal Hygiene}

“... Suruh mandi air

laut dan dii kompres

pakai

air

hangat..."(P4)

Satu partisipan

mengatakan bahwa

cara

menagani

scabies yaitu

dengan cara mandi air laut.

\section{Pembahasan}

\section{a. Pengalaman}

\section{Personal}

Pada Santri

Hygiene Scabies

suatu

penyakit yang mana penularannya lewat kontak langsung manusia. Partisiapan mengatakan bahwa scabies penularannya lewat kontak langsung manusia (Vica, C., Tarigan, R., Subchan, P., \& Widodo, A. (2018)). Scabies ini paling sering ditularkan lewat kontak langsung dari kulit penderita yang berlangsung lama atau berkepanjangan. Biasanya hal tersebut sering terjadi antara teman terdekatnya maupun anggota keluarga. Penyakit scabies juga sangat erat kaitannya dengan kebersihan

perorangan maupun lingkungan sekitar atau apabila terdapat banyak orang di lingkungan yang padat akan penghuninya

terutama seperti pondok pesantren (Mahmudah

Aslamiyah, H. F. (2018)).

Sejalan dengan hasil penelitiannya Nisa \& Rahmalia 2019 mengatakan penyakit scabies dapat menular dengan dua cara yaitu secara kontak langsung dan tidak langsung. Penularan secara kontak langsung terjadi ketika adanya kontak dengan kulit penderita misalnya berjabat tangan, tidur bersama, dan hubungan seksual. Adapun penularan dengan tidak langsung yaitu melalui benda yang 


\section{Husnul Khotimah: Pengalaman Personal Hygiene}

telah dipakai oleh penderita seperti pakaian, handuk, bantal dan lain-lain (Nisa, F. R., \& Rahmalia, D. (2019)).

Ma'rufi

mengatakan penyebab scabies yaitu karna kurangnya menjaga kebersihan diri. Menurut penelitian Nila Puspita Sari 2018 Personal hygiene yang kurang baik dapat meningkatkan resiko munculnya kejadian scabies. Kebiasaan buruk santri seperti menggantung dan menumpuk pakaian kotor didalam kamar santri Nila Puspita Sari, S. M. (2018). Sejalan dengan penelitian Parman 2017 bahwa kebersihan kulit yang kurang baik dapat meningkatkan

kejadian scabies, termasuk kebersihan kuku, kebersihan organ genital, kebersihan pakaian, kebersihan handuk, kebersihan tempat tidur, dan juga sprei (Mahmudah

Aslamiyah, H. F. (2018)).

Miftahurrizkqiyah \& Prasasty 2018 mengatakan dari hasil penelitiannya

kebiasaan

buruk santri dalam

keseharian yaitu saling meminjamkan barang seperti pakaian, handuk, sarung, bantal, kasur dan selimut, hal ini menjadi

faktor potensial bagi transmisi scabies (Miftahurrizqiyah， \& Prasasty, G. D. (2018)) Dari hasil penelitiannya Pratama 2016 mengatakan bahwa tinggal bersama dengan sekelompok orang seperti di pesantren berisiko mudah tertular penyakit scabies. Scabies kurang diperhatikan oleh para santri di Pondok Pesantren. Mereka menganggap kebiasaan mereka dalam menjaga 


\section{Husnul Khotimah: Pengalaman Personal Hygiene}

kebersihan diri sudah cukup dan tidak akan menimbulkan

masalah kesehatan khususnya penyakit kulit, dari beberapa penyakit kulit seperti scabies paling sering diakibatkan dari perilaku yang tidak sehat seperti menggantung pakaian dikamar, saling bertukar pakaian dan benda pribadi, seperti sisir dan handuk, dipengaruhi juga oleh pengetahuan yang kurang mengenai kebersihan diri (Pratama, I., Putri, N., Wibowo, D. A., \& Nugraheni, A. (2016)).

Partisipan mulai sadar setelah terkena scabies partisipan mulai pakai alat mandinya sendiri. Partisipan

mengatakan bahwa sudah mulai memakai alat mandinya sendiri setelah terkena penyakit scabies. Afriani 2017 mengatakan dari hasil penelitiannya penularan scabies terjadi karena faktor lingkungan dan perilaku yang tidak bersih diantaranya yaitu kebiasaan individu, seperti menggunakan

peralatan mandi secara bergantian (Afriani, B. (2017)). Sejalan dengan penelitiannya Parman 2017 megatakan faktor yang berperan dalam tingginya prevelensi scabies terkait dengan personal hygiene ialah buruknya perawatan santri seperti intensitas mandi, pemakaian handuk, dan alat mandi (Parman, Hamdani, Irwandi Rachman, A. P. (2017)).

Gejala scabies yang muncul yaitu rasa gatal pada waktu malam hari. Dari penelitian ini peneliti menemukan gejala scabies yang dikatakan oleh partisipan yaitu 


\section{Husnul Khotimah: Pengalaman Personal Hygiene}

timbul rasa gatal pada malam hari.

b. Keadaan Lingkungan Sekitar Santri

Partisipan lebih menjaga lingkungan sekitarnya setelah terkena penyakit scabies. Partisipan mengatakan setelah terkena scabies partisipan lebih menjaga kebersihan sekitarnya. Derajat kesehatan

dipengaruhi oleh beberapa factor, yaitu factor lingkungan, perilaku, pelayanan kesehatan dan factor keturunan (H.L Blum). Dari keempat factor ini yang paling mempengaruhi tinggi rendahnya derajat kesehatan adalah factor lingkungan dan perilaku. Penyakit kulit merupakan salah satu penyakit yang berhubungan dengan lingkungan dan perilaku manusia. Faktor lingkungan yang erat kaitannya dengan penyakit kulit antara penyediaan air bersih yang digunakan sebagai sumber air mandi dan cuci dari segi kualitas dan kuantitas (Hidayat, R. (2018)).

Sanitasi lingkungan perlu dijaga kebersihannya dimulai dari halaman, saluran pembuangan air dan jalan di lingkungan sekitar, penularan penyakit scabies terjadi bila kebersihan pribadi dan kebersihan lingkungan tidak terjaga dengan baik (Mayrona, C. T., Subchan, P., \& Widodo, A. (2018)) Zaira Naftassa 2017 mengatakan dari hasil penelitiannya tempat yang berpenghuni padat ditambah lingkungan yang tidak terjaga kebersihannya akan memudahkan transmisi dalam penularan tungau scabies (Zaira Naftassa, T. R. P. (2017).

Sanitasi lingkungan yang 


\section{Husnul Khotimah: Pengalaman Personal Hygiene}

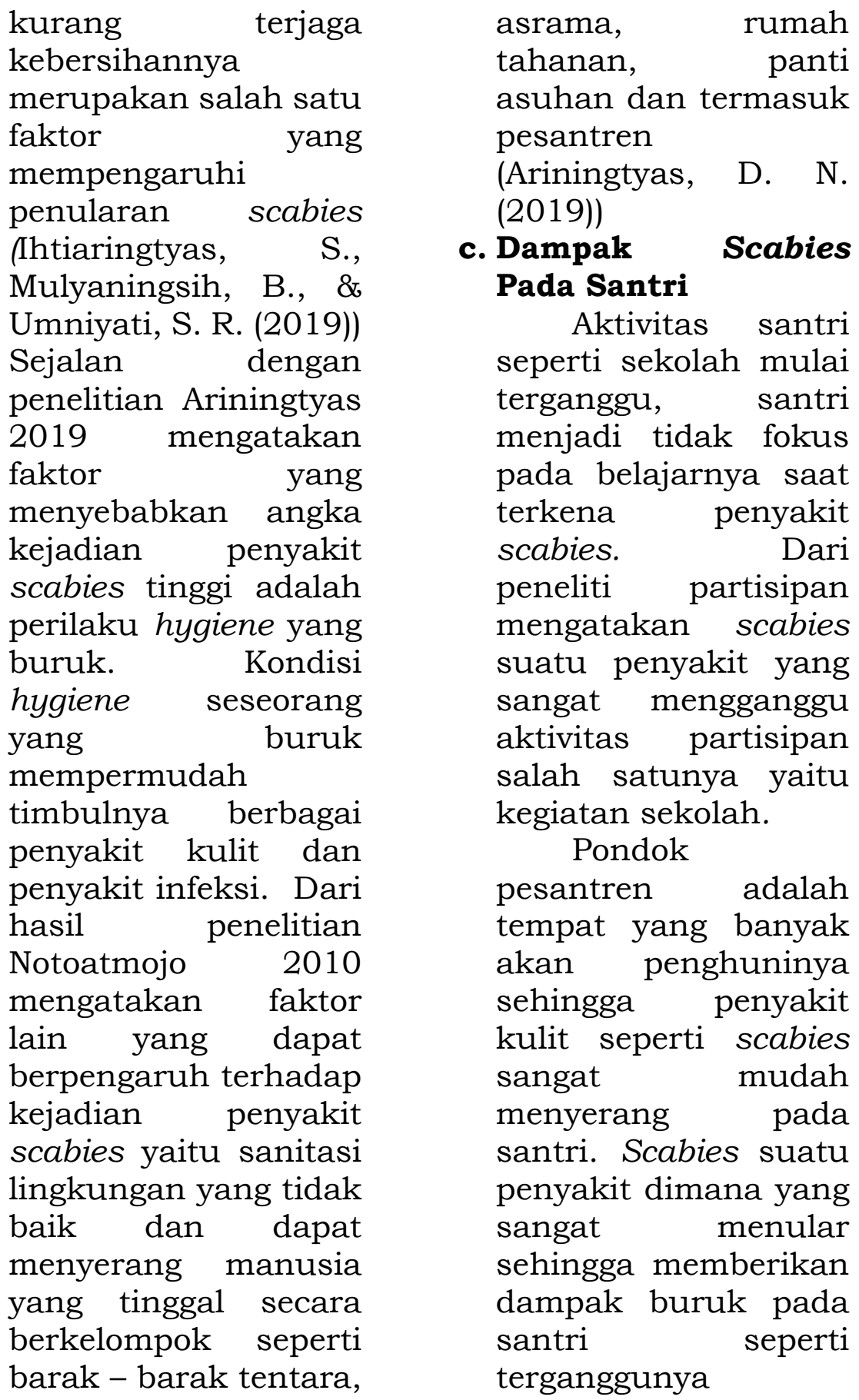




\section{Husnul Khotimah: Pengalaman Personal Hygiene}

aktifitas seperti sekolah (Sari, D. K., \& Ls, D. Y. (2017)). Dari Nuraini 2017 juga mengatakan bahwa dampak scabies menyebabkan

ketidaknyamaan pada penderita. Santri yang mengidap scabies terganggu kualitas hidupnya karena keluhan gatal yang hebat serta infeksi sekunder. Keluhan tersebut menurunkan kualitas hidup dan prestasi akademik (Nuraini, N. Wijayanti, R. A., Studi, P., Medik, R., Kesehatan, J., \& Negeri, P. (2017))

Dari

hasil penelitian Sutejo 2017 mengatakan Scabies sering diabaikan karena tidak mengancam jiwa, sehingga

penanganannya tidak menjadi prioritas. Namun scabies kronis dan berat dapat menimbulkan

komplikasi berbahaya. Scabies menimbulkan

ketidaknyamanan

karena gatal pada lesi berupa papul, vesikel, atau pustula yang terutama berada di sela-sela jari, yang merupakan tempat predileksi penyakit ini. Gatal yang dirasakan terutama saat malam hari menurunkan kualitas hidup dan prestasi akademik penderita (Sutejo, I. R., Rosyidi, V. A., \& Zaelany, A. I. (2017)).

Didukung oleh Saputra 2019 dari hasil penelitiannya mengungkapkan bahwa penyakit scabies yang di alami oleh santri yang sering terjadi pada bagian tubuh yang terserang adalah lipatan kulit bagian tangan, kaki dan selangkangan dimana terdapat kulit yang tipis dan lembab. Scabies ini tidak membahayakan manusia namun gejala utama yang dirasakan adalah 


\section{Husnul Khotimah: Pengalaman Personal Hygiene}

gatal dan mengganggu produktivitas dan aktivitas (Saputra, R. (2019).

Partisipan mengatakan bahwa pola tidurnya mulai terganggu karna rasa gatal yang sering muncul pada malam hari.

\section{d. Penanganan Santri} Dalam Mengatasi Scabies Peneliti

menemukan hal yang menarik dari partisipan dalam menangani scabies yaitu dengan mengoleskan salep, pergi periksa ke dokter dan ada yang mengatakan mandi air laut. Partisipan mengatakan bahwa dalam mengatasi scabies yaitu dengan cara mengoleskan salep, pergi periksa ke dokter, dan ada yang mandi air laut.

Pada dasarnya, pengetahuan

masyarakat tentang factor penyebab scabies masih sangat kurang, sehingga penyakit scabies ini dianggap sebagai penyakit yang biasa saja karena secara umum tidak membahayakan jiwa. Jika sudah terkena penyakit scabies, penanganan yang dapat dilakukan dengan mengoleskan salep khusus ke bagian tubuh yang terkena, pembersihan media-media yang dapat menyebabkan penyakit ini (Albarri, A. N. (2019). Dari Naziroh 2019 Mengatakan pencegahan dan pengobatan penyakit scabies masih rendah dilakukan oleh para santri di pondok pesantren.

Pengobatan yang biasa digunakan sebagian besar adalah salep yang biasanya digunakan pada malam hari (Nasiroh, A., Nu, N., \& Ardian, I. (2019).

Terapi yang sudah dilakukan oleh para santri yang menderita scabies 


\section{Husnul Khotimah: Pengalaman Personal Hygiene}

ialah dengan berobat dan menggukan obat dari dokter bagi yang sudah parah, penggunaan salep dan ada juga

yang memakai sabun sulfur. Selain itu, sabun yang digunakan oleh para santri dalam kehidupan sehari-hari adalah sabun cair biore, sabun lifeboy, sabun dettol, sabun sirih dan sabun holly, dan sabun-sabun lainnya. Naziroh 2019 mengatakan masalah penyakit kulit yang mengganggu kualitas hidup dan akademik santri di pesantren berupa keluhan gatal yang timbul dan berulang. Periksa ke Puskesmas sebagai rujukan pusat kesehatan untuk di berikan terapi atau pengobatan (Ghiffari, A., Ramayanti, I., Alfath, M. R., Rizki, P., $\&$ Badri, A. (2020). Pencegahan dan pengobatan yan tepat pada penyakit scabies, akan menurunkan angka kekambuhan yang timbul dari penyakit, hal ini dapat di hindari jika pasien patuh terhadap pengobatan dan melukakan pola hidup yang bersih dan sehat (Gutri, C. (2016).

\section{Daftar Pustaka}

Andareto, O. (2015). Penyakit Menular di Sekitar Anda (pertama; R. D. Aryanti, ed.). Jakarta.

Afiyanti, Y., \& Rachmawati. (2014). Metodelogi Penelitian Kualitatif dalam Keperawatan (II). Jakarta: PT RajaGrafindo Persada.

Afriani, B. (2017). Hubungan Personal Hygiene Dan Status Sosial Ekonomi Dengan Kejadian Skabies Di Pondok Pesantren, 2(1), 1-10.

Ahwath Riyadhy Ridwan, Sahrudin, K. I. (2017). Hubungan pengetahuan, personal hygiene, dan kepadatan hunian dengan gejala penyakit skabies pada santri di pondok 


\section{Husnul Khotimah: Pengalaman Personal Hygiene}

pesantren darul muklisin kota kendari 2017, 2(6), $1-8$.

Albarri, A. N. (2019). Analisis Edukasi Dokter dalam Pencegahan dan Penanganan Penyakit Scabies kepada Santri SMP di Pondok Pesantren.

Anggreni, P. M. D. (2019). Korelasi Faktor

Prediposisi Kejadian Skabies Pada AnakAnak Di Desa Songan, Kecamatan Kintamani, Kabupaten Bangli, Provinsi Bali. E-Jurnal Medika, 8(6), 4-11.

Ariningtyas, D. N. (2019). Analisis Karakteristik dan Higiene Individu dengan Kejadian Skabies di Lembaga Pembinaan Khusus Anak (LPKA) Kelas I Blitar Devi. Jurnal Keperawatan Muhammadiyah, 225231.

Bernigaud, Samarawickrama, G. R., Jones, M. K., \& Gasser, R. B. (2019). The
Challenge of Developing a Single-Dose Treatment for Scabies. Trends in Parasitology, 1-13. https://doi.org/10.1016/j. pt.2019.08.002.

Brown, R. G. (2009). Lecture Notes On Dermatologi (A. Safitri, ed.). Jakarta.

Creswell, J. W. (2010). Research Design. Pustaka Pelajar.

Desmawati, Dewi, A. P., \& Hasanah, O. (2015). Hubungan Personal Hygiene Dan Sanitasi Lingkungan Dengan Kejadian Skabies Di Pondok Pesantren AlKautsar Pekanbaru. Universitas Riau, 2(1), 628-637.

Dewi Fitriani S.Si., A. (2013). PENGOBATAN

MANDIRI (A. Tristanti, ed.). Jakarta.

Djaenudin Natadisastra. dr., S. P. (2009). parasitologi kedokteran ditinjau dari organ tubuh yang di serang (Ridad Agoes, ed.). Jakarta. 


\section{Husnul Khotimah: Pengalaman Personal Hygiene}

DWK. (2020). Biografi

Pondok Pesantren

Darullughah Wal

Karomah.

Gde, L., Ayuning, I., Mutiara, H., Suwandi, J. F., Ayu, R., Kedokteran, F., ... Lampung, U. (2019). Hubungan Skabies dengan Prestasi Belajar pada Santri Pondok Pesantren di Bandar Lampung Relationship Scabies with Learning Achievment on Santri Boarding School at Bandar Lampung. Medula, 8(2), 76-81.

Ghiffari, A., Ramayanti, I., Alfath, M. R., Rizki, P., \& Badri, A. (2020). Pemeriksaan mikroskopis keluhan kulit pada santri Pesantren Khazanah Kebajikan kota Palembang Abstrak Pondok pesantren Khazanah Kebajikan terletak di kecamatan Sako kota Palembang, . Humanity and Medicine, 1(1), 25-34. https://doi.org/10.32539/
Hummed.V1I1.24

Gutri, C. (2016). Pendahuluan Skabies merupakan infeksi parasit pada kulit yang disebabkan oleh Sarcoptes scabei var hominis . Tungau ini berukuran sangat kecil dan hanya bisa dilihat dengan mikroskop atau Penyakit skabies sering disebut kutu badan . Penyakit ini juga muda, 3(September), 8-14.

Herdyana, E., \& Qomari, N. U. R. (2016). Perbedaan Sikap Remaja Putri Usia 13-15 Tahun Sebelum Dan Sesudah diberi Penyuluhan Tentang Personal Hygiene (Di Pondok Pesantren Wali Barokah Kediri). Jurnal Kebidanan, 5(2), 67-75.

Hilma, U. D., \& Ghazali, L. (2014). Faktor-Faktor Yang Mempengaruhi Kejadian Skabies Di Pondok Pesantren Mlangi Nogotirto Gamping Sleman Yogyakarta. Jurnal Kedokteran Dan Kesehatan Indonesia, 


\section{Husnul Khotimah: Pengalaman Personal Hygiene}

6(3), $\quad$ 148-157.

https://doi.org/10.20885/

jkki.vol6.iss3.art6

Holstein, J. A. (2009).

Handbook of Qualitative

Research (I). yogyakarta.

Hidayat, R. (2018). Hubungan

Kondisi Ruangan Dan

Personal Hygiene

Terhadap Kejadian

Penyakit Kulit Pada

Asrama Putri Pondok

Pesantren Sultan

Hasanuddin Kab. Gowa.

Jurnal Sulolipu, 18(2), 195-203.

Ihtiaringtyas,

S.,

Mulyaningsih, B., \&

Umniyati, S. R. (2019).

Faktor Risiko Penularan

Penyakit Skabies pada

Santri di Pondok

Pesantren An Nawawi

Berjan Kecamatan

Gebang Kabupaten

Purworejo Jawa Tengah

Risk Factor of Scabies on

Students of An Nawawi

Islamic Boarding School

in Berjan Gebang

Subdistrict Purworejo

Distr. BALABA, 15(1), 83-90.
Kurniawan, B., \& Prabowo.

(2016).

Pengaruh

Pengetahuan dengan

Pencegahan Penyebaran

Penyakit

Skabies.

Majority |, 5(April), 6368.

Luthfa, I., Nikmah, S. A., Islam, U., \& Agung, S. (2019). Life Behavior Determines Scabies Disease. 35-41.

Laily Isro'in, S. A. (2012). Personal Hygiene Konsep, Proses dan Aplikasi dalam Praktik Keperawatan (pertama). Yogyakarta: Graha ilmu.

Mayrona, C. T., Subchan, P., Widodo, A., \& Lingkungan, S. (2018). Pengaruh Sanitasi Lingkungan Terhadap Prevalensi Terjadinya Penyakit Scabies Di Pondok Pesantren. Jurnal Kedokteran Diponegoro, 7(1), 100-112.

Mufidah, N., Imam, S., Darmiah, Muafidah, N., Santoso, I., \& Darmiah. (2016). Hubungan Personal Higiene dengan 


\section{Husnul Khotimah: Pengalaman Personal Hygiene}

Kejadian Skabies pada Santri Pondok Pesantren Al Falah Putera Kecamatan Liang Anggang. Journal of Health Science and Prevention, 1(1), 1-9. https://doi.org/ISSN 2549-919X.

Murlistyarini, S. (2015). Intisari Imlu Kesehatan Kulit dan Kelamin (pertama; S. Prawitasari, ed.). Jakarta: UB press.

Mahmudah Aslamiyah, H. F. (2018). Hubungan pengetahuan dengan sikap santri dalam mencegah skabies di pondok pesantren $\mathrm{x}$ banyuwangi tahun 2018 12. JIMKESMAS, 3(4), $1-9$.

Mayrona, C. T., Subchan, P., \& Widodo, A. (2018). Pengaruh Sanitasi Lingkungan Terhadap Prevalensi Terjadinya Penyakit Scabies Di Pondok Pesantren, 7(1), 100-112.

Miftahurrizqiyah, \& Prasasty, G. D. (2018). Kejadian
Skabies Berdasarkan

Pemeriksaan, $X X(\mathrm{X})$.

Nursalam. (2017). Metode

Penelitian

Ilmu

Keperawatan (empat).

Jakarta:

Salemba

Medika.

Nasiroh, A., Nu, N., \& Ardian, I. (2019). Hubungan Penggunaan Sabun Mandi ( Sulfur ) Dengan Kejadian Skabies Di Pondok Pesantren X Semarang The Relationship the use of Bath Soap ( Sulphur ) with The Incidence of Scabies in Pondok Pesantren X Semarang, (April), 19-27.

Nila Puspita Sari, S. M. (2018). Analisis Personal Higiene dan Pengetahuan dengan Analysis of Personal Hygiene and Knowledge with Incident of Scabies on Santri at Al-ikhwan Boarding. Jurnal Kesehatan Komunitas, 4(18), 63-67.

Nisa, F. R., \& Rahmalia, D. (2019). Faktor-faktor yang Berhubungan 


\section{Husnul Khotimah: Pengalaman Personal Hygiene}

dengan Kejadian Skabies pada Santri Putra di Pondok Pesantren Darurrahmah Gunung Putri Bogor. Jurnaal Kesehatan Masyarakat, 3(1), 16-23.

Nuraini, N., Wijayanti, R. A., Studi, P., Medik, R., Kesehatan, J., \& Negeri, P. (2017). Faktor Risiko Kejadian Scabies Di Pondok Pesantren Nurul Islam Jember ( Scabies Risk Factors In Pondok Pesantren Nurul Islam Jember ). Jurnal Ilmiah Inovasi, 1(2), 137-141.

Parman, Hamdani, Irwandi

Rachman, A. P. (2017).

Faktor Risiko Hygiene Perorangan Santri

Terhadap Kejadian

Penyakit Kulit Skabies

Di Pesantren Al-

Baqiyatushshalihat

Tanjung Jabung Barat Tahun 2017. Jurnal Ilmiah Universitas Batanghari Jambi, 17(3), 243-252.

Pratama, I., Putri, N., Wibowo, D. A., \& Nugraheni, A. (2016).
Perilaku Pencegahan

Skabies Di Pondok

Pesantren Darut Taqwa Bulusan Semarang Tahun 2016. Jurnal Kedokteran Di Ponogoro, 5(4), 10641073.

Prayogi, S., \& Kurniawan, B. (2016).

Pengaruh Personal Hygiene dalam Pencegahan Penyakit Skabies. MAJORITY, $5(5)$.

Sumiatin, T., \& Yunariyah, B. (2017). Effectiveness of Health Education on attitude about clean and healthy in prevention Scabies. Jurnal Ners Dan Kebidanan (Journal of Ners and Midwifery), 4(3), 224-227. https://doi.org/10.26699/ jnk.v4i3.art.p224-227

Sungkar, P. S., \& Park, S. (2016). Skabies. Jakarta: FKUI.

Susanto, H., \& Muzakki, M. (2017). Perubahan Perilaku Santri (Studi Kasus Alumni Pondok Pesantren Salafiyah di 


\section{Husnul Khotimah: Pengalaman Personal Hygiene}

Desa

Langkap

Kecamatan

Besuki

Kabupaten Situbondo).

Istawa:

Jurnal

Pendidikan Islam, 2(1), 1.

https://doi.org/10.24269/

ijpi.v2i1.361

Sylvie Puspita, Elly Rustanti, M. K. W. (2018). Hubungan Personal Hygiene Dengan

Kejadian Skabies Pada Santri.

Jurnal

Keperawatan, 2(3), 3338.

Santoso, S. (2016). Skin Infection: It's Must Know Dissase ( denny akhmadi A, ed.). Malang: UB.

Scholastica Fina Aryu Puspita, Ns., M. K. (2018). Asuhan Keperawatan Pada Pasien Dengan Gangguan Sistem Integumen (S. P. Mariyatul Qibtiyah., ed.). Yogyakarta: Pustaka Baru Press.

Sudarminta, J. (2002). Epistemologi pengantar filsafat pengetaahuan dasar (F. Mustafid, ed.). yogyakarta.

Sungkar, P. S., \& Park, S. (2016). Skabies.

Saputra, R. (2019). Hubungan Perilaku Hidup Bersih Dan Sehat (Phbs) Dengan Timbulnya Penyakit Scabies Pada Santri Rico Saputra 1), Wahidyanti Rahayu H 2), Ronasari Mahaji Putri 3) 1), 4(1).

Sari, D. K., \& Ls, D. Y. (2017). Karakteristik penghuni pondok pesantren terhadap prevelensi penyakit kulit scabies di pondok pesantren putri desa gedok wetan kabupaten malang, 5(2), 30-44.

Setiawati, M. E., \& Karima, U. Q. (2019). Optimalisasi Manajemen Phbs Pada Santri Di Smp It AlHidayah Bogor Tahun 2019, 83-92. 